\title{
Short Communication: Application of bacteriocin from Lactobacillus plantarum SRCM 100434 strain isolated from okara as a natural preservative in beef sausage
}

\author{
SALAM N. ARITONANG", ELLY ROZA ${ }^{p \psi}$, AFRIANI SANDRA \\ Faculty of Animal Science, Universitas Andalas. Jl. Raya Unand, Kampus Limau Manis, Padang 25163, West Sumatra, Indonesia. Tel.: +62-751-71464 \\ ext 617, Fax.: +62-751-71464, "email: snaritonang@ansci.unand.ac.id, "elroz@ansci.unand.ac.id, "vvafrianisandra@ansci.unand.ac.id
}

Manuscript received: 15 October 2019. Revision accepted: 27 April 2020.

\begin{abstract}
Aritonang SN, Roza E, Sandra A. 2020. Short Communication: Application of bacteriocin from Lactobacillus plantarum SRCM 100434 strain isolated from okara as a natural preservative in beef sausage. Biodiversitas 21: 2240-2245. Lactic Acid Bacteria (LAB) can be found in food and most of the LAB have beneficial effects for humans as potential probiotics. LAB isolated from okara (soy milk pulp) produces antimicrobial compounds called bacteriocins which can be used as natural preservatives in sausages. This study aims to determine the effectiveness of this bacteriocin from LAB as a natural preservative in sausages. The bacteriocin was isolated from Lactobacillus plantarum SRCM 100434 strain isolated from Okara. Completely Randomized Design (CRD) was used in $4 \mathrm{X} 4$ factorial pattern by three replicates The first factor was the percentage addition of bacteriocin (B): $0 \%\left(\mathrm{~B}_{0}\right), 0.3 \%\left(\mathrm{~B}_{1}\right), 0.6 \%\left(\mathrm{~B}_{2}\right)$ and $0.9 \% \mathrm{v} / \mathrm{b}\left(\mathrm{B}_{3}\right)$. The second factor was the length of sausage storage time at $4{ }^{\circ} \mathrm{C}(\mathrm{L}): 0$ days $(\mathrm{L} 0), 4$ days $\left(\mathrm{L}_{1}\right), 8$ days $\left(\mathrm{L}_{2}\right)$ and 12 days $\left(\mathrm{L}_{3}\right)$. The observed variables were moisture content, protein, fat, $\mathrm{pH}$, total aerobic bacteria, and sausage fatty acid profile. The results showed that the content of protein, fat, and the bacterial count was significantly influenced by the interaction of the percentage addition of bacteriocin and storage time. $\mathrm{pH}$ was significantly affected by bacteriocin dose and storage time but was not affected by the interaction of other factors. The moisture content of the sausage was significantly affected by storage time. The results of this study showed that sausages treated with $0.9 \%$ bacteriocin $\left(\mathrm{B}_{3}\right)$ with a maximum storage time of 12 in the refrigerator was still safe to be consumed.
\end{abstract}

Keywords: Bacteriocin, lactic acid bacteria, preservative, storage time, sausage

\section{INTRODUCTION}

Lactic Acid Bacteria (LAB) are bacteria that produce lactic acid from the breakdown of carbohydrates and antibacterial substances including bacteriocins and hydrogen peroxide, which can inhibit the growth of microbes. Therefore it can be used as a preservative or natural antimicrobial (Alakomi et al. 2000). The effectiveness of $\mathrm{LAB}$ in inhibiting pathogenic and destroying bacteria is influenced by the density and composition of the media and the strain. Lactic acid bacteria such as Lactobacillus lactis and Streptococcus thermophillus are used to inhibit food spoilage and pathogenic bacteria and preserve the nutritive quality of food (Heller 2001). Lactic Acid Bacteria can be isolated from various natural sources and are produced especially during the fermentation process of some foods. LABs are probiotics that are Generally Recognized as Safe (GRAS) therefore they have no health risks health. Previous studies showed that LAB can reduce cholesterol (Liong and Shah 2005; Jeun et al. 2010), increased the nutritional value of food, control intestinal infections and improve digestion because LABs produce lactase in the digestive tract of humans and animals (LeBlanc et al. 2008).

One important characteristic of LAB is its ability to produce antimicrobial compounds bacteriocins that inhibit the growth of pathogenic microorganisms, therefore it can be used as bio-preservatives (Savadogo et al. 2006). There are several classes of bacteriocins, i.e. simple peptides or proteins and others contain lipid molecules (Salminen 2004). They act as bactericidal or bacteriostatic agents against other bacteria. They are easily degraded by proteolytic enzymes and they can inhibit the growth of microorganisms that phylogenetically close to bacteria that produced bacteriocins. (De-Vuyst and Leroy 2007). The bacteriocins produced by LAB can inhibit the growth of pathogenic microbes and those involved in decomposition such as Bacillus cereus, Clostridium botulinum, Clostridium perfringens, Listeria monocytogenes, and Staphylococcus aureus (Diop et al. 2007). The application of bacteriocins in food does not affect the taste and appearance of the product. Bacteriocins produced by LAB can be utilized in the form of supernatant, partially purified, or more completely purified products (Woraprayote et al. 2016). Bacteriocins are commonly used in the food industry especially in fermented foods to inhibit the growth of bacterial contaminants that cause food spoilage and food-borne diseases (Abdelbasset et al. 2008). The antimicrobial compounds may affect bacterial metabolism and toxin production (Rolfe 2000).

Sausages are meat products with the addition of fillers and binders such as vegetable flour or starch, seasonings, and other permitted food ingredients to be placed in sausage casings (Hui et al. 2001). In Indonesia, sausages 
must contain at least $75 \%$ of meat (SNI 1995). According to the USDA (2001), fresh sausages stored in the fridge $\left(4^{\circ} \mathrm{C}\right)$ have a shelf life of 1-2 days.

The shelf life of fresh sausages can be extended by adding nitrite, but excessive consumption of nitrites can be harmful to health (Stringer and Pin 2005). Nitrites can bind to the amino and amides present in meat proteins to form carcinogenic nitrosamines (Zarringhalami et al.2009). The use of nitrite as a preservative in making sausages can be reduced by the addition of bacteriocin. The addition of $0.3 \%$ bacteriocin extracted from Lactobacillus plantarum 2C12 was able to inhibit the growth of Escherichia coli, Staphylococcus aureus, and Salmonella typhimurium in meatballs without any changes of the taste (Arief et al. 2012).

Lactic Acid Bacteria in this study were isolated from Okara. Okara is the residue left from ground soybeans after filtration to produce soy milk, however, it still has a high nutritional content. Okara contains $28.36 \%$ crude protein, $5.52 \%$ fat, $7.6 \%$ crude fiber, lysine and methionine amino acids, and vitamin B (Hsieh and Yang 2003), therefore it can be used as growth media for bacteria including lactic acid bacteria. The aim of the research was to study the role of bacteriocin from L. plantarum SRCM 100434 strain isolated from okara as a natural preservative in beef sausage.

\section{MATERIALS AND METHODS}

\section{Materials}

Bacteriocin used in this study was isolated from $L$. plantarum strain SRCM 100434 from okara (Aritonang et al. 2017).

\section{Research design}

The study used a Completely Randomized Design (CRD) in $4 \times 4$ factorial pattern by three replicates The first factor was four levels of bacteriocin addition (B), i.e., $0 \%$ $\left(\mathrm{B}_{0}\right), 0.3 \%\left(\mathrm{~B}_{1}\right), 0.6 \%\left(\mathrm{~B}_{2}\right)$ and $0.9 \%\left(\mathrm{~B}_{3}\right)$. The second factor was the length of sausage storage time $(\mathrm{L})$ at $4^{\circ} \mathrm{C}$ : 0 days $\left(\mathrm{L}_{0}\right), 4$ days $\left(\mathrm{L}_{1}\right), 8$ days $\left(\mathrm{L}_{2}\right)$ and 12 days $\left(\mathrm{L}_{3}\right)$.

\section{Data analysis}

The data were statistically analyzed using the Statistical Analysis System (SAS). Mean comparisons were carried out by Duncan's Multiple Range Test (DMRT) with significance at $\mathrm{P}<0.05$.

\section{Bacteriocin extraction (Yang et al. 2012)}

Ten ml of L. plantarum SRCM 100434 strain culture was inoculated into $90 \mathrm{ml}$ of MRS-B media, then incubated in a shaker incubator at a speed of $100 \mathrm{rpm}$ at $37^{\circ} \mathrm{C}$ for 24 hours. After incubation, the growth media was centrifuged at $4,000 \mathrm{rpm}$ at $4{ }^{\circ} \mathrm{C}$ for 25 minutes and then filtered using a $0.22 \mu \mathrm{m}$ membrane filter. The crude bacteriocin supernatant was used as sausages preservative.

\section{The process of making sausages (Modified Erkkila 2001)}

Beef ribs (meat and fat) were washed thoroughly, and then added $3 \%$ salt and $20 \%$ ice/ice water followed by grinding until smooth. Ground meat was added with $15 \%$ tapioca flour, $10 \%$ skim milk, and spices and a preservative (garlic $0.4 \%$, onion $0.6 \%$, ginger $0.5 \%$, sugar $1.5 \%$, salt $2 \%$, nitrite $150 \mathrm{ppm}$, and pepper $0.15 \%$ ) as a filler and mixed until well blended. Sausage mixture was cured at 4$7^{\circ} \mathrm{C}$ for 24 hours. The sausage mixture was divided into 48 parts and added with supernatant containing bacteriocin according to the treatment: $0 \%\left(\mathrm{~B}_{0}\right), 0.3 \%\left(\mathrm{~B}_{1}\right), 0.6 \%\left(\mathrm{~B}_{2}\right)$ and $0.9 \%\left(\mathrm{~B}_{3}\right)$. Stuff mixture into casings and steamed at $80^{\circ} \mathrm{C}$ for 40 minutes, and then cooled down to room temperature for 2 hours, followed by storing in a refrigerator according to the treatment of storage time: 0 days $\left(\mathrm{L}_{0}\right), 4$ days $\left(\mathrm{L}_{1}\right), 8$ days $\left(\mathrm{L}_{2}\right)$ or 12 days $\left(\mathrm{L}_{3}\right)$. Every treatment has three replicates

\section{Determination of chemical composition}

Chemical properties of sausages: The moisture, protein, and fat content were determined according to AOAC (2005).

Fatty acid composition: was determined by extracting samples using chloroform: methanol (2: 1) solution. The extract was partitioned with methanol using the Morrison and Smith method (1964). Fatty acids were separated on a capillary column $(30 \mathrm{~m} \times 0.32 \mathrm{~mm}$ with $0.25 \mu \mathrm{m}$ film thickness) that connected to a Gas Chromatography (GC, Model Star 3600, Palo Alto, USA). The GC was conditioned at $250^{\circ} \mathrm{C}$ for the injection port and $300^{\circ} \mathrm{C}$ for detectors. The free fatty acids in the samples were identified by comparing their retention time to those of standard fatty acids. The results were expressed as relative percentages based on the total peak area.

Total aerobic bacteria count (Fardiaz 1992): Five grams of the sausage was crushed until smooth, then put into a flask containing $45 \mathrm{ml}$ of $\mathrm{NaCl}$ solution and homogenized. Take one $\mathrm{ml}$ of the solution and diluted to $10^{-7}$ and $10^{-8}$. One hundred $\mu \mathrm{l}$ from each dilution was pipetted and placed on Plate Count Agar (PCA) media in a petri dish. Petri dishes were incubated at $37^{\circ} \mathrm{C}$ for 48 hours in an inverted position. The number of bacteria was determined by the plate count method and Standard Plate Count (SPC).

\section{RESULTS AND DISCUSSION}

\section{Moisture content}

Table 1. showed that the moisture content of beef sausages was not affected by the interaction between bacteriocin dose and sausage storage time $(\mathrm{P}>0.05)$ but it was significantly affected by storage time $(\mathrm{P}<0.05)$. The level of bacteriocin addition did not affect significantly moisture content $(\mathrm{P}>0.05)$.

Storage time of 12 days $\left(\mathrm{L}_{3}\right)$ result in the highest level of moisture content in sausages but it was not significantly different from moisture content in 8 days $\left(\mathrm{L}_{2}\right)$ and 4 days $\left(\mathrm{L}_{1}\right)$ storage time. Naturally, food degraded during storage which can result in increased moisture content (Ray and 
Bhuna 2008). The results of this study showed that 12 days of storage at $4^{\circ} \mathrm{C}$ did not significantly change the chemical composition of sausages, but the moisture content was slightly increased. The increase of moisture content did not reduce sausage quality, because the moisture content still meets the Indonesian National Standard (INS 2015) requirements which is less than $67 \%$. Arief et al. (2017) showed that the addition of bacteriocin derived from $L$. plantarum IIA-1A5 produces sausages with the moisture content of $57.57 \%$. The addition of bacteriocin supernatant in this study did not significantly affect the moisture content of beef sausages $(\mathrm{P}>0.05$ because the primary content of bacteriocin is proteins.

\section{Protein}

The protein content of sausages was not significantly affected by the interaction between the bacteriocin dose and the storage time $(\mathrm{P}<0.05)$ (Table 2). Increasing bacteriocin dose up to $0.9 \%$ (B3) result in increasing protein content due to the addition of protein from bacteriocin (Jack et al. 1995). This is because bacteriocins are a precursor protein that carries $\mathrm{N}$-terminals in the main peptide that remains it is in the cytoplasm to play a role again in the synthesis of bacteriocins (Ray 2004).

Table 1. The effect of bacteriocin dose and storage time to the moisture content of sausages

\begin{tabular}{llllll}
\hline Treatment & $\mathbf{L}_{\mathbf{0}}$ & $\mathbf{L}_{\mathbf{1}}$ & $\mathbf{L}_{\mathbf{2}}$ & $\mathbf{L}_{\mathbf{3}}$ & Average \\
\hline $\mathrm{B}_{0}$ & 52.74 & 52.12 & 53.17 & 54.04 & 53.02 \\
$\mathrm{~B}_{1}$ & 52.60 & 52.32 & 53.59 & 54.20 & 53.18 \\
$\mathrm{~B}_{2}$ & 52.85 & 52.37 & 53.45 & 54.10 & 53.19 \\
$\mathrm{~B}_{3}$ & 52.75 & 52.79 & 52.87 & 53.69 & 53.11 \\
Average & $52.74^{\mathrm{a}}$ & $52.40^{\mathrm{b}}$ & $53.27^{\mathrm{b}}$ & $54.01^{\mathrm{b}}$ & \\
\hline
\end{tabular}

Note: ${ }^{\mathrm{a}, \mathrm{b}}$ Means in the same column with a different letter are significantly different $(\mathrm{P}<0.05)$. L: Length of storage time. B: Percentage of bacteriocin

Table 2. The effect of bacteriocin dose and storage time to the protein content of sausages (\%)

\begin{tabular}{lllll}
\hline Treatment & $\mathbf{L}_{\mathbf{0}}$ & $\mathbf{L}_{\mathbf{1}}$ & $\mathbf{L}_{\mathbf{2}}$ & $\mathbf{L}_{\mathbf{3}}$ \\
\hline $\mathrm{B}_{0}$ & $18.37^{\mathrm{b}}$ & $18.22^{\mathrm{b}}$ & $18.31^{\mathrm{b}}$ & $18.05^{\mathrm{a}}$ \\
$\mathrm{B}_{1}$ & $18.72^{\mathrm{d}}$ & $18.48^{\mathrm{ab}}$ & $18.46^{\mathrm{ab}}$ & $18.21^{\mathrm{b}}$ \\
$\mathrm{B}_{2}$ & $19.07^{\mathrm{f}}$ & $18.87^{\mathrm{e}}$ & $18.70^{\mathrm{d}}$ & $18.51^{\mathrm{c}}$ \\
$\mathrm{B}_{3}$ & $19.53^{\mathrm{g}}$ & $19.40^{\mathrm{g}}$ & $19.43^{\mathrm{g}}$ & $19.39^{\mathrm{g}}$ \\
\hline
\end{tabular}

Note: ${ }^{\mathrm{a}-\mathrm{g}}$ : Means with a different letter are significantly different $(\mathrm{P}<0.05)$

Table 3. The effect of bacteriocin dose and storage time to the fat content of sausages $(\%)$

\begin{tabular}{|c|c|c|c|c|}
\hline Treatment & $\mathbf{L}_{\mathbf{0}}$ & $\mathbf{L}_{1}$ & $\mathbf{L}_{2}$ & $\mathbf{L}_{3}$ \\
\hline $\mathrm{B}_{0}$ & $6.11^{\mathrm{c}}$ & $6.06^{\mathrm{ab}}$ & $6.01^{\mathrm{a}}$ & $6.07^{\mathrm{b}}$ \\
\hline $\mathrm{B}_{1}$ & $6.40^{\mathrm{g}}$ & $6.30^{\mathrm{f}}$ & $6.19^{\mathrm{e}}$ & $6.15^{\mathrm{d}}$ \\
\hline $\mathrm{B}_{2}$ & $6.47^{\mathrm{i}}$ & $6.40^{\mathrm{g}}$ & $6.42^{\mathrm{h}}$ & $6.22^{\mathrm{e}}$ \\
\hline $\mathrm{B}_{3}$ & $6.52^{\mathrm{j}}$ & $6.50^{\mathrm{ij}}$ & $6.48^{\mathrm{ij}}$ & $6.47^{\mathrm{i}}$ \\
\hline
\end{tabular}

The protein content of sausages containing $0.9 \%$ bacteriocin was slightly decreased after being stored for 12 days at $4-10^{\circ} \mathrm{C}$, but it did not significantly different from sausages that were not stored $\left(\mathrm{L}_{0} \mathrm{~B}_{3}\right)$. The addition of bacteriocin to $0.9 \%$ did not change the nutrient content of sausages after being stored for 12 days. It might be caused by the ability of bacteriocins to inhibit the growth of microorganisms such as proteolytic bacteria that could potentially break down protein (Collins et al. 2010).

The protein content of sausages in this study ranged from $18-19 \%$, which was above the minimum protein content of $13 \%$, according to the Indonesian National Standard (SNI 2015). these results were in line with the results of Melia (2018) that the addition of bacteriocin from Lactobacillus fermentum L23 produced sausages with protein content range $17-18 \%$.

\section{Fat}

The fat content of the sausages was significantly affected by the interaction between bacteriocin dose and sausage storage time $(\mathrm{P}<0.05)$ (Table 3$)$. The addition of bacteriocin increased the fat content of sausages regardless of storage time. Increasing the dose of bacteriocin results in increasing the fat content of sausages.

The increase of fat content in sausages containing bacteriocin due to lipid content in bacteriocins (Ouattara et al. 2011). Sausages containing $0.9 \%$ bacteriocin (B3) stored for 12 days at cold temperatures $\left(4-10^{\circ} \mathrm{C}\right)$ have the highest fat content but are not significantly different from sausages that are stored for 4 days and 8 days.

These results indicated that the addition of bacteriocin can maintain the fat content of beef sausages at cold storage for 12 days. Bacteriocins contain antimicrobial compounds that inhibit lipid decomposition thereby reducing fat degradation. When bacteriocin peptides attach to target bacterial cell membranes, the positive end of the peptide binds to the fatty acids present in the membrane phospholipid, and then was separated by formation of pores which finally the bacterial death was in own cell (Song and Zheng 2015). The fat content of sausages in this study was around $6 \%$ which was below the maximum level (20\%) according to the Indonesian National Standard (INS 2015). This result was in line with the result of Melia (2018) that the addition of bacteriocin from L. fermentum L23 produced sausage with the fat content of $6.85 \%$.

pH

Table 4. showed that the $\mathrm{pH}$ of beef sausages was affected significantly by the bacteriocin dose and storage period $(\mathrm{P}<0.05)$ but was not affected by the interaction between these two factors $(\mathrm{P}>0.05)$.

Table 4. The effect of bacteriocin dose and storage time to the $\mathrm{pH}$ of sausages

\begin{tabular}{llllll}
\hline Treatment & $\mathbf{L}_{\mathbf{0}}$ & $\mathbf{L}_{\mathbf{1}}$ & $\mathbf{L}_{\mathbf{2}}$ & $\mathbf{L}_{\mathbf{3}}$ & Average \\
\hline $\mathrm{B}_{0}$ & 5.40 & 5.40 & 5.50 & 5.50 & $5.45^{\mathrm{a}}$ \\
$\mathrm{B}_{1}$ & 5.40 & 5.40 & 5.40 & 5.50 & $5.40^{\mathrm{a}}$ \\
$\mathrm{B}_{2}$ & 5.30 & 5.40 & 5.40 & 5.40 & $5.40^{\mathrm{a}}$ \\
$\mathrm{B}_{3}$ & 5.20 & 5.30 & 5.30 & 5.30 & $5.30^{\mathrm{b}}$ \\
Average & $5.32^{\mathrm{a}}$ & $5.39^{\mathrm{b}}$ & $5.40^{\mathrm{b}}$ & $5.43^{\mathrm{b}}$ & \\
\hline
\end{tabular}

Note: ${ }^{\mathrm{a}, \mathrm{b}}$ Means in the same column/row with a different letter are significantly different $(\mathrm{P}<0.05)$ 
Table 5. The effect of bacteriocin dose and storage time to the Total Aerobic Bacteria (x $10^{3} \mathrm{Cfu} / \mathrm{mL}$ )

\begin{tabular}{lllll}
\hline Treatment & $\mathbf{L}_{\mathbf{0}}$ & $\mathbf{L}_{\mathbf{1}}$ & $\mathbf{L}_{\mathbf{2}}$ & $\mathbf{L}_{\mathbf{3}}$ \\
\hline $\mathrm{B}_{0}$ & $14.37^{\mathrm{a}}$ & $14.86^{\mathrm{bc}}$ & $16.57^{\mathrm{e}}$ & $19.33^{\mathrm{f}}$ \\
$\mathrm{B}_{1}$ & $14.30^{\mathrm{a}}$ & $14.60^{\mathrm{b}}$ & $15.57^{\mathrm{c}}$ & $16.05^{\mathrm{d}}$ \\
$\mathrm{B}_{2}$ & $14.27^{\mathrm{a}}$ & $14.65^{\mathrm{b}}$ & $15.35^{\mathrm{c}}$ & $16.06^{\mathrm{d}}$ \\
$\mathrm{B}_{3}$ & $14.26^{\mathrm{a}}$ & $14.37^{\mathrm{a}}$ & $14.98^{\mathrm{bc}}$ & $15.70^{\mathrm{c}}$ \\
\hline Note: ${ }^{\text {a-f: }}$ Means with a different letter are significantly different \\
$(\mathrm{P}<0.05)$
\end{tabular}

The highest addition of bacteriocin $\left(0.9 \%, \mathrm{~B}_{3}\right)$ produced the lowest sausage $\mathrm{pH}$ (5.2). The decrease in $\mathrm{pH}$ of beef sausages due to the amino acids in bacteriocin which contain hydrogen atoms in the carboxyl group dissociates to produce $\mathrm{H}^{+}$ions thereby increasing acidity and reducing $\mathrm{pH}$.

The length of storage time from 4 to 12 days $\left(\mathrm{L}_{1}, \mathrm{~L}_{2}\right.$, $\mathrm{L}_{3}$ ) did not significantly affect the $\mathrm{pH}$ of sausages but slightly higher than control $\left(\mathrm{L}_{0}\right)$. An increase of sausage $\mathrm{pH}$ accord along with an increase of storage duration in low temperature due to enzyme activity and chemical decomposition of compounds such as proteins which results in the production of alkaline compounds such as indole, scatole, and cadaverine (Suradi 2012).

\section{Total aerobic bacteria}

Total aerobic bacteria were significantly affected by the interaction between the bacteriocin dose and the storage time of sausage $(\mathrm{P}<0.05)$ (Table 5). The addition of bacteriocin significantly inhibits the growth of aerobic bacteria during storage. Bacteriocin addition to $0.9 \%$ (B3) suppressed the increase of total aerobic bacteria. Total aerobic bacteria in the $\mathrm{B}_{3} \mathrm{~L}_{3}$ treatment $(0.9 \%$ bacteriocin, 12 days of storage) was $15.70 \times 10^{3} \mathrm{CFU} / \mathrm{mL}$ which was not significantly different from B2L2 treatment ( $0.6 \%$ bacteriocin, 8 days of storage) which was $15.35 \mathrm{x}$ $10^{3} \mathrm{Cfu} / \mathrm{mL}$.

Total aerobic bacteria in sausages with $\mathrm{B}_{3} \mathrm{~L}_{3}$ treatment were higher compared to the results of Wibowo et al. (2017) showed that the addition of the bacteriocin supernatant from $L$. plantarum IBL-2 to fresh ground beef and stored for 12 days had total aerobic bacteria of $0.96 \mathrm{x}$ $10^{4} \mathrm{CFU} / \mathrm{ml}$. Because L. plantarum IBL-2 of Wibowo research added with nisin amide. While the addition of nisin influenced decreased bacterial growth. So that why total aerobic bacterial was lower than the result of this study.

Result of this research is also higher than Arief et al. (2017) study which is Total aerobic bacteria in sausages with the addition of bacteriocin from L. plantarum IIA-1A5 is $3.66 \times 10^{3} \mathrm{CFU} / \mathrm{mL}$. It caused the storage time of sausage at Arief's et al studied up to $9^{\text {th }}$ days. Total aerobic bacteria are still under the maximum number $\left(1 \times 10^{5}\right)$ permitted by SNI (1995). The results suggest that $0.9 \%$ bacteriocin addition to sausages that sored for 12 in the refrigerator are still safe for consumption. SNI (1995). Therefore sausages with the addition of $0.9 \%$ bacteriocin stored for 12 days in the refrigerator are still safe for consumption.

\section{Fatty acid profile}

The percentage of bacteriocin addition and storage time affected the lipolysis process in sausages, results in changing the profile of fatty acids. Fatty acid profile of sausages was presented in Table 6. showed there were 13 types of fatty acids were detected in all samples. Percentage of stearic acid (C18:0), linolenic acid (C18:3n3), erucic acid (C20:1n9), and arachidonic acid (C20:4n6) were significantly different among treatments ( $\mathrm{P}$ $<0.05)$. The highest level of C18:0 (13.85\%) was in sausages treated with $0.9 \%$ bacteriocin without storage $\left(\mathrm{B}_{3} \mathrm{~L}_{0}\right)$, while the lowest was sausages without the addition of bacteriocin and stored 12 days (B0L3).

The results suggest that the highest dose of bacteriocin $(0.9 \%)$ inhibited fat decomposition by lipolytic bacteria and result in a high level of stearic acid. Bacteriocins are known to inhibit lipolytic bacteria (Abdelbasset et al. 2008). Levels of highly unsaturated fatty acids such as $\mathrm{C} 18: 3 \mathrm{n} 3$ and $\mathrm{C} 20: 4 \mathrm{n} 6$ were significantly higher in sausages which were treated with $0.9 \%$ bacteriocin and stored for 4 days $\left(\mathrm{B}_{3} \mathrm{~L}_{2}\right)$ were $0.67 \%$ and $0.49 \%$ respectively.

Unsaturated Fatty Acids (UFA) levels and n6/n3 ratio also differed among treatments. UFA levels were higher in bacteriocin-treated sausages than controls and being the highest was in sausages treated with $0.9 \%$ bacteriocin on 0 days of storage $\left(B_{3} L_{0}\right)$. The ratio of $n 6 / n 3$ was lower in sausages treated with high bacteriocin than control, and being the lowest ratio was sausages with $0.9 \%$ bacteriocin with a storage period of 12 days. UFA especially PUFAs such as $\mathrm{C} 18: 3 \mathrm{n} 3$ have a highly significant influence on human health (Jump 2002), and a high ratio of $n 6 / n 3$ is good for health (Krauss et al. 1998). Differences in fatty acid content between treatments due to differences in the lipase activity of microbes (Chen et al. 2017). Fatty acid levels may be influenced by the antimicrobial activity of bacteriocin that capable of inhibiting the growth of microorganisms (Collins et al. 2010).

In conclusion, the protein and fat content, $\mathrm{pH}$, total aerobic bacteria, and fatty acid profile of the beef sausages were significantly influenced by bacteriocin dose and storage time. The moisture content of sausages was significantly influenced by storage time. The addition of $0.9 \%$ bacteriocin produces sausages that are still suitable for consumption after 12 days of storage at the refrigerator based on the chemical composition and total aerobic bacteria.

\section{ACKNOWLEDGEMENTS}

This research was funded by BOPTN Research Funding from the Andalas University, Padang, Indonesia, Ministry of Research and Technology of Higher Education of the Republic of Indonesia through contract No. 34/UN.16.17/PP.RGB/ LPPM/2018. We are very grateful to the Rector of Andalas University and the Minister of Research and Technology of Higher Education for funding this work. 
Table 6. Percentage of fatty acid in sausage (\%)

\begin{tabular}{|c|c|c|c|c|c|c|c|c|c|c|c|c|c|c|c|c|}
\hline & B0.0 & B0.4 & B0.8 & B0.12 & B1.0 & B1.4 & B1.8 & B1.12 & B2.0 & B2.4 & B2.8 & B2.12 & B3.0 & B3.4 & B3.8 & B3.12 \\
\hline C14:0 & 1.40 & 1.41 & 1.48 & 1.46 & 1.51 & 1.51 & 1.45 & 1.57 & 1.52 & 1.52 & 1.52 & 1.55 & 1.56 & 1.52 & 1.55 & 1.58 \\
\hline C16:0 & 22.45 & 22.70 & 22.85 & 22.15 & 22.87 & 22.72 & 22.15 & 22.18 & 23.25 & 23.05 & 22.85 & 22.35 & 23.60 & 23.35 & 23.20 & 23.15 \\
\hline $\mathrm{C} 16: 1 \mathrm{n} 7$ & 1.25 & 1.25 & 1.23 & 1.15 & 1.18 & 1.38 & 1.25 & 1.23 & 1.57 & 1.40 & 1.48 & 1.35 & 1.85 & 1.60 & 1.67 & 1.45 \\
\hline C18:0 & $12.47^{\mathrm{b}}$ & $12.40^{\mathrm{b}}$ & $12.20^{\mathrm{b}}$ & $11.25^{\mathrm{a}}$ & $12.85^{\mathrm{bc}}$ & $12.25^{\mathrm{b}}$ & $12.37^{\mathrm{b}}$ & $11.87^{\mathrm{a}}$ & $13.57^{\mathrm{c}}$ & $13.05^{\mathrm{c}}$ & $13.23^{\mathrm{c}}$ & $12.15^{\mathrm{b}}$ & $13.85^{\mathrm{d}}$ & $13.50^{\mathrm{cd}}$ & $13.25^{\mathrm{c}}$ & $12.87^{\mathrm{bc}}$ \\
\hline C18:1n9 & 40.90 & 40.60 & 40.53 & 39.95 & 40.85 & 40.63 & 40.67 & 40.45 & 40.95 & 40.70 & 40.25 & 40.00 & 40.73 & 40.75 & 40.78 & 40.55 \\
\hline $\mathrm{C} 18: 2 \mathrm{n} 7$ & 0.15 & 0.14 & 0.13 & 0.10 & 0.16 & 0.14 & 0.13 & 0.12 & 0.17 & 0.15 & 0.15 & 0.14 & 0.18 & 0.15 & 0.15 & 0.10 \\
\hline C18:2n6 & 15.51 & 15.50 & 15.48 & 15.27 & 15.78 & 15.73 & 15.65 & 15.35 & 16.41 & 16.47 & 16.35 & 16.05 & 16.75 & 16.53 & 16.45 & 16.25 \\
\hline C18:3n6 & 0.06 & 0.05 & 0.05 & 0.04 & 0.06 & 0.06 & 0.05 & 0.04 & 0.07 & 0.07 & 0.07 & 0.06 & 0.05 & 0.07 & 0.06 & 0.04 \\
\hline C18:3n3 & $0.52^{\mathrm{a}}$ & $0.52^{\mathrm{a}}$ & $0.50^{\mathrm{a}}$ & $0.49^{\mathrm{a}}$ & $0.52^{\mathrm{a}}$ & $0.51^{\mathrm{a}}$ & $0.50^{\mathrm{a}}$ & $0.48^{\mathrm{a}}$ & $0.57^{\mathrm{b}}$ & $0.53^{\mathrm{ab}}$ & $0.51^{\mathrm{a}}$ & $0.47^{\mathrm{a}}$ & $0.62 b^{c}$ & $0.67^{\mathrm{c}}$ & $0.57^{\mathrm{b}}$ & $0.54^{\mathrm{ab}}$ \\
\hline C20:1n9 & $0.62^{\mathrm{a}}$ & $0.83^{\mathrm{bc}}$ & $0.75^{\mathrm{b}}$ & $0.85^{\mathrm{c}}$ & $0.87^{\mathrm{c}}$ & $0.83^{b}$ & $0.81^{\mathrm{b}}$ & $0.76^{\mathrm{b}}$ & $0.95^{\mathrm{d}}$ & $0.87^{\mathrm{c}}$ & $0.85^{\mathrm{c}}$ & $0.79^{\mathrm{a}}$ & $0.98^{\mathrm{d}}$ & $0.95^{\mathrm{d}}$ & $0.87^{\mathrm{c}}$ & $0.84^{\mathrm{bc}}$ \\
\hline $\mathrm{C} 20: 4 \mathrm{n} 6$ & $0.32^{\mathrm{ab}}$ & $0.30^{\mathrm{a}}$ & $0.26^{\mathrm{a}}$ & $0.24^{\mathrm{a}}$ & $0.37 \mathrm{~b}$ & $0.33^{\mathrm{ab}}$ & 0.30 & $0.27^{\mathrm{a}}$ & $0.39^{c}$ & $0.37^{\mathrm{b}}$ & $0.37^{\mathrm{b}}$ & $0.31^{\mathrm{a}}$ & $0.45^{\mathrm{cd}}$ & $0.49^{\mathrm{d}}$ & $0.39^{c}$ & $0.35^{\mathrm{ab}}$ \\
\hline C20:5n3 & 0.01 & 0.01 & 0.009 & 0.008 & 0.013 & 0.013 & 0.011 & 0.009 & 0.014 & 0.013 & 0.011 & 0.009 & 0.015 & 0.015 & 0.012 & 0.009 \\
\hline C22:4n6 & 0.13 & 0.13 & 0.12 & 0.10 & 0.16 & 0.15 & 0.12 & 0.11 & 0.16 & 0.16 & 0.13 & 0.11 & 0.18 & 0.16 & 0.14 & 0.12 \\
\hline SFA & 38.70 & 38.70 & 38.20 & 38.00 & 39.70 & 39.67 & 38.50 & 38.10 & 39.87 & 39.65 & 39.10 & 38.80 & 39.92 & 39.85 & 39.50 & 38.80 \\
\hline UFA & $55.40^{\mathrm{b}}$ & $55.25^{\mathrm{ab}}$ & $55.03^{\mathrm{a}}$ & $54,92^{\mathrm{a}}$ & $57.90^{\text {de }}$ & $57.50^{\mathrm{d}}$ & $56.47^{c}$ & $56.40^{c}$ & $59.20^{\mathrm{f}}$ & $58.12^{\mathrm{e}}$ & $57.50^{\mathrm{d}}$ & $57.01^{\mathrm{cd}}$ & $62.20^{\mathrm{g}}$ & $61.81^{\mathrm{h}}$ & $61.35^{\mathrm{h}}$ & $60.95^{\mathrm{g}}$ \\
\hline MUFA & 42.42 & 42.40 & 42.35 & 42.05 & 42.92 & 42.75 & 42.45 & 41.95 & 42.81 & 42.80 & 42.68 & 42.49 & 42.98 & 42.87 & 42.62 & 42.43 \\
\hline PUFA & 17.43 & 17.37 & 17.15 & 17.05 & 18.00 & 17.87 & 17.63 & 17.57 & 18.02 & 18.01 & 17.85 & 17.55 & 18.23 & 18.05 & 17.86 & 17.51 \\
\hline $\mathrm{n} 6 / \mathrm{n} 3$ & $29.60^{\mathrm{cd}}$ & $29.15^{\mathrm{bc}}$ & $28.87^{\mathrm{b}}$ & $28.85^{\mathrm{b}}$ & $29.89^{\mathrm{d}}$ & $29.57^{\mathrm{cd}}$ & $29.03^{\mathrm{bc}}$ & $28.67^{b}$ & $29.87^{\mathrm{e}}$ & $29.76^{\mathrm{de}}$ & $29.15^{\mathrm{bc}}$ & $28.90^{\mathrm{b}}$ & $29.30^{c}$ & $28.45^{\mathrm{a}}$ & $28.37^{\mathrm{a}}$ & $28.23^{\mathrm{a}}$ \\
\hline
\end{tabular}




\section{REFERENCES}

Abdelbasset M, Djamila K. 2008. Antimicrobial activity of autochthonous lactic acid bacteria isolated from Algerian traditional fermented milk "raib". Afr J Biotechnol 7 (16): 2908-2914.

Alakomi AL, Saarela S, Sandholom M, Kala L, Helander. 2000. Lactic acid permeabilized Gram-negative bacteria by disrupting the outer membrane. Appl Environ Microbiol 66: 2001-2005.

AOAC. 2005. Official Method of Analysis of AOAC International $18^{\text {th }}$ ed AOAC International, Gaithersburg, MD.

Arief II, Wulandari Z, Sindya ES. 2017. Application of Purified Bacteriocin from Lactobacillus plantarum IIA-IAS as Biopreservative of Beef Sausage. Pak J Nutr 16 (6): 444-450.

Aritonang SN, Roza E, Rossi E. 2017. Isolation and identification of lactic acid bacteria from okara and evaluation of their potential as candidate probiotics. Pak J Nutr 16 (8): 618-628.

Cahyadi W. 2006. Kedelai Khasiat dan Teknologi. Bumi Aksara. Jakarta. [Indonesian]

Chen Q, Kong B, Han Q, Xia X, Xu L. 2017. The role of bacterial fermentation in lipolysis and lipid oxidation in Harbin dry sausages and its flavor development. LWT Food Sci. Technol 77: 389-396.

Collins B, Cotter PD, Hill C, Ross R P. 2010. Applications of Lactic AcidBacteria - Produced Bacteriocins in Biotechnology of Lactic Acid Bacteria, Novel Application. Willey-Blackwell, New York.

De-Vuyst L, Leroy F. 2007. Bacteriocins from lactic acid bacteria: production, purification, and food applications. J Mol Microbiol Biotechnol 13: 194-199.

Diop M, Dubois-Dauphin BR, Tine E. 2007. Bacteriocin producers from traditional food products. BASE Biotechnol Agron Soc Environ 11 (4): 275-281.

Erkkila S. 2001. Bio protective and Probiotic Meat Starter Cultures for The Fermentation of Dry Sausages. [Dissertation]. Department of Food Technology, University of Helsinki, Helsinki.

Fardiaz S. 1992. Analisa Mikrobiologi Pangan. PT. Raja Grafindo Persada, Kerjasama dengan PAU Antar Universitas Pangan dan Gizi, Institut Pertanian Bogor, Bogor. [Indonesian]

Heller KJ. 2001. Probiotic bacteria in fermented foods: product characteristics and starter organisms. Am J Clin Nutr 73: 374S-9S.

Hsieh C, Yang FC. 2003. Reusing soy residue for the solid-state fermentation of Ganoderma lucidum. Bioresour Technol 80: 21-25.

Hui YK, Nip WK, Rogers RW, Young OA. 2001. Meat Science and Application. Marcel Dekker Inc., New York.

Jack RW, Tagg JR, Ray B. 1995. Bacteriocins of Gram-positive bacteria. Microbiol Mol Biol Rev 59 (2) : 171-200.

Jeun J, Kim S, Cho S, Jun H, Park H, Seo J. 2010. Hypocholesterolemic effects of Lactobacillus plantarum KCTC3928 by increased bile acid excretion in C57BL/6 Mice. Nutrition 26 (3): 321-330.

Jump DB. 2002. The Biochemistry of $n-3$ polyunsaturated fatty acid. J Biol Chem 277: 8755-8758.

Krauss RM, Decklel RJ, Ernst N, Fisher E, Howard BV, Kopp RH, Kotchen T, Lichtenstein. AH, McGill HC, Pearson TA, Prewitt TE, Stone NJ, Hen LV, Weinberg R. 1996. Dietary guidelines for healthy American adults. A statement for health professionals from the nutrition committee. Amer Heart Assoc Circul 94: 1795-1800.

Kusumawati N. 2000. Peranan bakteri asam laktat dalam menghambat Listeria monocytogenes pada bahan pangan. Jurnal Tekhnologi Pangan dan Gizi 1 (1): 14-28. [Indonesian]
LeBlanc JG, Clier FL, Bensaada M, de Giori GS, Guerekobaya T, Sesma F, Juillard V, Rabot S, Piard JC. 2008. Ability of Lactobacillus fermentum to overcome host $\alpha$-galactosidase deficiency, as evidenced by reduction of hydrogen excretion in rats consuming soya $\alpha$-galactooligosaccharides. BMC Microbiol 8: 22. DOI: 10.1186/1471-2180-822 .

Liong MT, Shah NP. 2005. Acid and bile tolerance and cholesterol removal ability of lactobacilli strains. J Dairy Sci 88: 55-66.

Melia S. 2018. Potensi Isolat Bakteri Asam Laktat Dari Susu Kerbau sebagai Probiotik dan Penghasil Bakteriosin Untuk Pangan Fungsional. [Dissertation]. Program Studi Ilmun Peternakan, Fakultas Peternakan Universitas Andalas, Padang. [Indonesian]

Morrison WR, Smith LM. 1964. Preparation of fatty acid methyl ester a dimethyl acetals from lipids with boron fluoride methanol. J Lipid Res 5: 600-608.

Ouattara L, Koudou J, Zongo C, Barro N, Savadogo A. 2011. Antioxidant and antibacterial activities of three species of lannea from Burkina Faso. J Appl Sci 11 (1): 157-162.

Ray B, Bhuna A. 2008. Fundamental Food Microbiology. 4th ed. CRC Press, Boca Raton, FL.

Ray B. 2004. Fundamental Food Microbiology. 3rd ed. CRC Press, New York.

Rolfe. 2000. The role of probiotic cultures in the control of gastrointestinal health. J Nutrition 130: 396-402.

Salminen S, Atte VW, Arthur O. 2004. Lactic Acid Bacteria. Marcel Dekker Inc., New York

Savadogo AA, Ouattara TC, Bassole HNI, Traore SA. 2006. Bacteriocins and lactic acid bacteria-a minireview. Afr J Biotechnol 5 (6): 678683.

Song H, Zheng W. 2015. Antimicrobial natural product the battle against microbial pathogen: basic science, technology advances and educational program. In: Mendez-vilas A (ed.). The Battle Against Microbial Pathogen: Basic Science, Technology Advances and Educational Program. Formatex Research Center, Spain.

Standard Nasional Indonesia 1995. SNI. No. 7388-2009. Batas Maksimum Cemaran Mikroba dalam Pangan. Jakarta. [Indonesian]

Standard Nasional Indonesia. 1995. SNI. 01-3820-1995. Sosis Daging. Dewan Standarisasi Nasional, Jakarta. [Indonesian]

Stringer SC, Pin C. 2005. Microbial risk associated with salt reduction in certain foods and alternatives for preservation. Institute of Food Research, Norwich, UK

Suradi K. Pengaruh lama penyimpanan pada suhu ruang terhadap perubahan nilai $\mathrm{pH}, \mathrm{TVB}$ dan total bakteri daging kerbau. Jurnal Ilmu Ternak 2 (2): 9-12. [Indonesian]

USDA. 2001. Refrigerator and Freezer Storage Chart. U.S Food and Drug Administration, Washington, D.C.

Wibowo MS, Muzakiah I, Nurhayati B, Armina TI. 2017. Production and application of Lactobacillus plantarumIBL-2 bacteriocins as meat product biopreservatives. Indon Food Nutr Progr 14 (1): 68-76.

Woraprayote W, Malila Y, Sorapukdee S, Swetwiwathana A, Benjakul S, Visessanguan W. 2016. Bacteriocin from lactic acid bacteria and their applications in meat and meat products. Meat Sci. DOI: 10.1016/ j. meatsci.2016.04.004

Yang E, Lihua F. Yueming J, Craig D, Sherry F. 2012. Antimicrobial activity of bacteriocin-producing lactic acid bacteria isolated from cheeses and yogurts. AMB Express 2: 48. DOI: 10.1186/2191-0855$2-48$

Zarringhalami S. Sahari MA, Esfehani H. 2009. Partial replacement of nitrite by annato as a color additive in sausage. Meat Sci 81: 281-284. 